\title{
Ocena zmian wyników prób w testach wstań-usiądź oraz wstań-idź u kobiet po sześćdziesiątym roku życia, uczestniczących w zajęciach gimnastycznych Badanie pilotażowe
}

\section{The assessment of changes of the results in the 30-second chair stand and 8-foot up-and-go tests within women over the age of sixty, participating in the gymnastics class. A pilot study}

The ageing process leads to irreversible changes within the functioning of the whole human organism. One of the problems which the seniors have to face is sarcopenia, that is a progressive loss of the skeletal muscles mass, which results in the loss of strength. Regularly performed physical exercises may significantly slow down this process and even cause muscle hypertrophy.

A 13-week programme of the shaping gymnastic exercises has been drawn up to improve the strength of the lower body muscles. 25 women aged $60-81$ took part in this programme. Strength of the lower limbs and dynamic agility have been assessed relying on the 30-second chair stand and 8-foot up-and-go Fullerton tests.

The results of the statistical analysis indicate the growth of strength of the lower muscles on average by $24 \%$ and the dynamic agility by $6 \%$. The improved muscle persistence has also been observed - at the end of the cycle of research the group has achieved better results in the postworkout attempts than in the pre-workout ones.

The shaping gymnastic exercises regularly performed by women over the age of sixty improve the strength of lower limb muscles, dynamic agility and muscle persistence. 


\section{Wprowadzenie}

Starzenie się człowieka to nieodwracalny proces, prowadzący do licznych zmian inwolucyjnych dotykających całego organizmu, zarówno w sferze fizycznej, jak i umysłowej. Jednym z istotnych problemów, z którymi muszą zmagać się ludzie starsi, jest pogorszenie sprawności funkcjonalnej, objawiające się coraz większymi trudnościami w związku z wykonywaniem czynności dnia codziennego (Activities of daily living, ADL). Odpowiedzialna za ten stan jest między innymi sarkopenia, czyli zespół objawów, polegający na utracie masy mięśni szkieletowych wraz z upośledzeniem ich funkcji (spadek siły). Ludzie starsi, poza obniżeniem komfortu życia oraz częściową lub całkowitą utratą samodzielności, narażeni są także na ryzyko groźnych kontuzji. Zmniejszenie się siły mięśniowej wraz z pogorszeniem koordynacji ruchowej wpływają bezpośrednio na wzrost ryzyka upadków. Niemal połowa z nich skutkuje jakimś urazem, w tym 10-15\% to między innymi ciężkie urazy głowy i krwiaki wewnątrzczaszkowe, natomiast 5-6\% to złamania kości, w tym najpoważniejsze - złamania nasady bliższej kości udowej (Osiński, 2013). W przypadku starszych kobiet 10-20\% upadków prowadzi do śmierci (Thornby, 1995).

Wydaje się, że potrzeba kształtowania oraz zachowania możliwie najwyższej sprawności fizycznej u seniorów z czasem będzie jeszcze większa. Dzięki rozwojowi nauk medycznych możemy korzystać z coraz trafniejszych metod diagnostycznych jak i skutecznej terapii, mających na celu przedłużenie życia oraz poprawę jego jakości. Według danych Głównego Urzędu Statystycznego średnia długość życia Polaków w ciągu najbliższych czterech dekad wydłuży się z 81,1 do 87,5 lat u kobiet oraz 73,1 do 82,1 lat w przypadku mężczyzn. Dodatkowo, obserwujemy wyraźną tendencję starzenia się społeczeństwa. Obecnie w Polsce odsetek osób powyżej 60 roku życia wynosi 19,6\%, jednak prognozy na rok 2050 ukazują wzrost tego wskaźnika do $29,3 \%$ (GUS, 2014).

Jak zauważają Rubenstein i Josephson (2002), mimo istnienia ogólnej zgody co do faktu, że procesowi starzenia towarzyszy spadek siły mięśniowej, w dużej mierze jest on efektem choroby i braku aktywności ruchowej, a nie samego starzenia się.

Jednym z najbardziej dostępnych i skutecznych sposobów na zachowanie zdrowia do późnych lat życia jest aktywność ruchowa (Drabik, 1999), jednak warunkiem rozpoczęcia procesu aktywizacji osób starszych jest świadomość korzyści, które z niej płyną (Żak, 2000). Niestety, z badań opublikowanych przez Centrum Badania Opinii Społecznej w roku 1997 wynika, że zaledwie 7\% respondentów deklaruje regularne podejmowanie ćwiczeń fizycznych, kolejne 7\% - dość często, $12 \%$ - sporadycznie, a aż 74\% - wcale (Maciatowicz, 2003). W 2007 roku organizacja American College of Sports Medicine opublikowała wytyczne odnośnie do aktywności fizycznej osób dorosłych. Zakładają one, że w celu poprawy lub utrzymaniu stanu zdrowia należy codzienne wykonywać ćwiczenia ruchowe przez 30 min (optymalnie), lub 3 razy tygodniowo po 20 min (minimalnie) (Haskell et al. 2007). 
Skelton wykazał, że wśród zdrowych seniorów istnieje dodatnia korelacja pomiędzy siłą mięśni a zdolnością do wykonywania zadań z zakresu aktywności funkcjonalnej, głównie wstawania z krzesła oraz chodzenia (Skelton et al., 1994). Natomiast Frontera i wsp., przeprowadzając badania na 12-osobowej grupie mężczyzn w wieku 60-72 lat, poddanych 12-tygodniowemu cyklowi treningu oporowego, zauważają, że proces hipertrofii mięśni możliwy jest do uzyskania nawet $w$ wieku senioralnym (Frontera et al., 1988).

Przedmiotem analizy autorów artykułu jest wpływ 13-tygodniowego, autorskiego programu aktywności ruchowej dla seniorów, opartego na zestawie gimnastycznych ćwiczeń kształtujących, ukierunkowanych na wzmacnianie siły dolnych partii mięśniowych, jak również poprawę koordynacji ruchowej, na wyniki w testach wstań-usiądź (siła dolnych partii mięśniowych) oraz wstań-idź (zwinność dynamiczna). Światowa Organizacja Zdrowia (WHO) określiła początek starzenia się (tzw. wczesna starość) na 60. rok życia (Zych, 2001); taki też wiek minimalny przyjęto jako determinantę kwalifikacji do programu badań.

Podjęto próbę sformułowania odpowiedzi na następujące pytania:

1. Czy odpowiednio dobrane i regularnie wykonywane gimnastyczne ćwiczenia kształtujące poprawiają siłę dolnych partii mięśni u kobiet po 60. roku życia?

2. Czy odpowiednio dobrane i regularnie wykonywane gimnastyczne ćwiczenia kształtujące poprawiają wytrzymałość dolnych partii mięśni u kobiet po 60. roku życia?

3. Czy istnieje zależność pomiędzy zmianą siły dolnych partii mięśni a wiekiem u kobiet po 60. roku życia?

4. Czy istnieje zależność pomiędzy zmianą siły dolnych partii mięśni a wskaźnikiem BMI u kobiet po 60. roku życia?

Należy zaznaczyć, że niniejsza praca ma charakter badania pilotażowego. Analiza statystyczna uzyskanych wyników oraz odpowiedzi na powyższe pytania mają na celu jedynie ułatwienie postawienia trafnych hipotez $w$ docelowym badaniu głównym i nie powinno się na ich podstawie wyciągać wniosków per se.

\section{Materiał}

Do programu zgłosiło się 39 kobiet - słuchaczek poznańskiego Uniwersytetu III Wieku oraz Akademii III Wieku. Osoby biorące udział w badaniach zostały poinformowane o korzyściach oraz ewentualnych zagrożeniach związanych z uczestnictwem w zajęciach gimnastycznych. Ostatecznie analizie statystycznej poddano wyniki badań 25 kobiet, spełniających poniższe kryteria doboru:

- wiek 60 lat i więcej;

- samodzielność w chodzeniu oraz utrzymywaniu pozycji pionowej ciała (niekorzystanie ze sprzętu ortopedycznego);

- brak przewlekłych chorób oraz przeciwskazań lekarskich do ćwiczeń;

- stan psychiczny pozwalający na swobodną komunikację i wykonywanie poleceń;

- pisemne wyrażenie zgody na udział w badaniach; 
- udział w co najmniej w 23 z 25 jednostek treningowych;

- Udział we wszystkich trzech sesjach pomiarowych.

Średni wiek wyniósł 68,68 lat. Z 95\% prawdopodobieństwem przedział 65,871,56 lat obejmuje średni wiek populacji. Najmłodsza osoba miała 61, najstarsza 84 lata. Wiek poszczególnych osób odchylał się przeciętnie od wieku średniego o 6,97 lat.

Tabela 1. Wiek oraz BMI uczestników badań

\begin{tabular}{|l|c|c|c|c|c|c|c|}
\hline Czynnik & Średnia & $\begin{array}{c}\text { Ufność } \\
-\mathbf{9 5 \%}\end{array}$ & $\begin{array}{c}\text { Ufność } \\
\mathbf{9 5 \%}\end{array}$ & Mediana & Min & Max & $\begin{array}{c}\text { Odchylenie } \\
\text { standardowe }\end{array}$ \\
\hline Wiek & 68,68 & 65,80 & 71,56 & 67,00 & 61,00 & 84,00 & 6,97 \\
\hline BMI & 25,73 & 24,20 & 27,27 & 26,08 & 18,67 & 33,87 & 3,71 \\
\hline
\end{tabular}

Źródło: badania własne.

\section{Metody}

Program ćwiczeń. Trening oparto na gimnastycznych ćwiczeniach kształtujących. Odbywały się w okresie marzec - czerwiec 2014 roku. Były opracowane oraz prowadzone przez pracowników Zakładu Gimnastyki Akademii Wychowania Fizycznego w Poznaniu. Każdy trening trwał 45 min i odbywał się dwa razy w tygodniu w godzinach przedpołudniowych - łącznie, na przestrzeni 13 tygodni, odbyło się 25 jednostek treningowych.

Głównym celem ćwiczeń kształtujących jest wyrobienie prawidłowej postawy ciała przez oddziaływanie specjalnie dobranymi formami ćwiczeń na układ ruchowy człowieka (Młokosiewicz, 1979). Dają one prowadzącemu możliwość ścisłego ukierunkowania na konkretne partie mięśniowe, wpływając tym samym na poprawę pożądanych cech motorycznych - szczególnie siły, gibkości oraz koordynacji ruchowej. Dzięki powtarzalności ruchów, uczestnik zajęć może skupić się na prawidłowym i precyzyjnym ćwiczeniu. Prowadzący w łatwy sposób może kontrolować intensywność treningu, dostosowując do danej grupy ilość powtórzeń oraz charakter i dynamikę poszczególnych ćwiczeń.

Przyjęty do badań program zakłada wykorzystywanie ruchów głównie o charakterze równoważnym oraz oporowym, gdzie obciążeniem jest własne ciało. Z uwagi na wiek grupy zdecydowano, że większa część ćwiczeń będzie przeprowadzona w pozycjach niskich, tj. w klęku, siadzie i leżeniu, zwiększa to bowiem poziom bezpieczeństwa uczestników, minimalizując ryzyko utraty równowagi i ewentualnych konsekwencji z tym związanych. Dodatkowo, w przypadku nadmiernego zmęczenia w trakcie zajęć, niskie pozycje ułatwiają ćwiczącemu chwilowy odpoczynek. Zajęcia rozpoczynały się około pięciominutową rozgrzewką, angażującą najbardziej podstawowe ruchy, jak marsz w miejscu oraz wznosy, przenosy i opusty ramion. Następnie wykonywano ćwiczenia w pozycjach wysokich, nastawione na pracę zginaczy i prostowników ud (kształtowanie siły dolnych 
partii mięśniowych). W kolejnych etapach zajęć stosowano coraz niższe pozycje, a ćwiczenia były ukierunkowane na równowagę oraz koordynację. Końcowa faza treningu to ćwiczenia w leżeniu, mające na celu rozciągnięcie mięśni. Ostatnim elementem były oddechowe ćwiczenia relaksacyjne, pozwalające na odpoczynek i uspokojenie organizmu po wysiłku. Całkowicie zrezygnowano z energicznych form ruchu, takich jak podskoki lub rzuty kończyn.

Zajęcia odbywały się z udziałem akompaniatora pianisty. Obecność muzyki wykonywanej na żywo ułatwia ćwiczącym rozpoczęcie, zakończenie oraz utrzymanie równomiernego tempa w trakcie każdego ćwiczenia. Za pomocą odpowiednio dobranych utworów muzycznych można również podkreślić charakter poszczególnych ruchów, pomagając w jego prawidłowym wykonaniu. Akompaniament muzyczny dodatkowo podnosi atrakcyjność zajęć, znacznie je uprzyjemniając i dodając ćwiczącym energii oraz motywacji.

Program badań. Łącznie odbyły się trzy pomiary: na początku cyklu (pierwszy trening), w środku (tydzień 6 , trening nr 13) oraz na zakończenie cyklu (tydzień 13, trening nr 25). Na każdy pomiar składały się dwie próby: przedwysiłkowa, bezpośrednio przed treningiem, oraz powysiłkowa - tuż po ćwiczeniach. U każdej z uczestniczek wykonano pomiary antropometryczne wysokości ciała (jednorazowo na początku cyklu badań) oraz masy ciała - przed każdymi zajęciami. Określono wskaźnik BMI uczestniczek jako iloraz uśrednionej masy ciała $(\mathrm{kg})$ i kwadratu wysokości ciała $(\mathrm{m})$.

Do oceny zmian zdecydowano się skorzystać z dwóch testów Functional Strength (FS): Chair Stand (wstań-usiądź) oraz 8 Foot Up \& Go (wstań-idź), jako że z siedmiu propozycji baterii testowej Fullerton, to one w największym stopniu dotyczą siły dolnych partii mięśniowych, odpowiedzialnych za utrzymanie równowagi statycznej oraz zwinności dynamicznej.

Test wstań-usiądź. Badany siedzi na standardowym krześle z siedziskiem na wysokości $45 \mathrm{~cm}$. Celem zapewnienia stabilności podczas wstawania, krzesło dotyka oparciem ściany. Ręce badanego skrzyżowane są na klatce piersiowej. Na ustaloną komendę ćwiczący wstaje do pełnego wyprostu tułowia, a następnie powraca do pozycji wyjściowej. Wynikiem jest liczba prawidłowo wykonanych sekwencji powstań-siadów. Test należy zademonstrować. Uczestnik ma możliwość wykonania jednej próby.

Test wstań-idź. Badany siedzi na standardowym krześle z siedziskiem na wysokości $45 \mathrm{~cm}$, ręce spoczywają na udach, stopy oparte o podłogę w dowolnym ustawieniu. W odległości 8 stóp $(\sim 2,44 \mathrm{~m})$ na wprost od krzesła ustawiony jest pachołek. Na ustaloną komendę uczestnik wstaje z krzesła, idzie w stronę pachołka, okrąża go z dowolnej strony, po czym wraca na pierwotne miejsce i siada na krześle. W próbie liczy się czas - należy wykonać ją możliwie najszybciej, jednak nie wolno biec. Testujący stoi w pobliżu i w razie konieczności służy pomocą - asekuruje. Próbę należy zademonstrować. Wynikiem jest najlepszy czas z dwóch prób, zapisywany z dokładnością do 0,1 s.

Analiza statystyczna została wykonana za pomocą oprogramowania STATISTICA 10 firmy StatSoft. Wykorzystano w niej podstawową statystkę opisową, wyrażoną w postaci wartości średnich z odchyleniem standardowym. Wyniki poszczególnych prób zostały uśrednione, a następnie porównane za pomocą 
testu t dla prób zależnych. Celem określenia istotności różnic w trzech kolejnych pomiarach skorzystano z jednoczynnikowej analizy wariancji, a następnie wykonano porównanie posthoc za pomocą testu Bonferoniego. Współczynnik siły związku dla tabel dwudzielczych został określony za pomocą testu chi-kwadrat ze wskazaniem współczynnika V-Cramera.

Dla przejrzystości podczas omawiania wyników badań, przyjęto następujące skróty: Test wstań-usiądź: WU, test wstań-idź: WI. Numer kolejnego badania zapisywany w postaci cyfr arabskich: pierwsze (1) środkowe (2) oraz końcowe (3). O tym, czy omawiana wartość dotyczy pomiaru przed- czy powysiłkowego, będzie świadczył przyrostek przed lub po.

\section{Wyniki}

Test WU. Początkowa, przedwysiłkowa wartość w teście WU wyniosła średnio 17,8 powtórzeń, by zaraz po treningu zmaleć do 15,84 powtórzeń. Po 6 tygodniach ćwiczeń, podczas kolejnego badania średnie wyniki grupy wyniosły 18,56 przed i 18,8 powtórzeń po treningu, przy czym różnica ta została określona jako nieistotna. Podczas ostatniego badania średnie wyniosły: 20,16 przed i 21,56 powtórzeń po treningu.

Tabela 2. Liczba uzyskanych powtórzeń w teście wstań-usiądź. Próby przed- i powysiłkowe

\begin{tabular}{|l|c|c|c|c|c|c|}
\hline Wyszczególnienie & WU1przed & WU1po & WU2przed & WU2po & WU3przed & WU3po \\
\hline Średnia & 17,80 & 15,84 & 18,56 & 18,80 & 20,16 & 21,56 \\
\hline $\begin{array}{l}\text { Odchylenie } \\
\text { standardowe }\end{array}$ & 3,15 & 2,70 & 4,23 & 3,58 & 3,59 & 4,10 \\
\hline $\begin{array}{l}\text { Istotność } \\
(p<0,05)\end{array}$ & \multicolumn{2}{|c|}{0,0006} & \multicolumn{2}{c|}{0,6639} & \multicolumn{2}{c|}{0,0002} \\
\hline
\end{tabular}

Źródło: badania własne.

Po określeniu wpływu treningu na uzyskiwane wartości, uśredniono wyniki prób przed- i powysiłkowych. Uzyskano następujące wyniki: 16,82 dla pierwszego pomiaru, 18,68 dla drugiego oraz 20,86 powtórzeń podczas pomiaru końcowego. Wyniki wraz z określeniem prawdopodobieństwa dla testów posthoc, za pomocą testu Bonferoniego obrazuje tabela 3. Istotność przy $p<0,05$.

Określono wartość zmiany uśrednionego wyniku pomiędzy pierwszym a ostatnim badaniem dla każdej osoby. Zaobserwowano istotną $(p=0,006)$ korelację ujemną o umiarkowanej sile $(-0,53)$ pomiędzy wiekiem a zmianami w uzyskiwanych wynikach testu wstań-usiądź. Nie stwierdzono istotnej różnicy pomiędzy wskaźnikiem BMl a ww. zmianami. 
Tabela 3. Uśrednione wyniki testu wstań-usiądź wraz z wynikami testu post hoc Bonferoniego

\begin{tabular}{|l|c|c|c|}
\hline \multirow{2}{*}{ Wyszczególnienie } & \multicolumn{3}{|c|}{ Badanie } \\
\cline { 2 - 4 } & $\{\mathbf{1}\} \mathbf{1 6 , 8 2}$ & $\{\mathbf{2}\} \mathbf{1 8 , 6 8}$ & $\{\mathbf{3}\} \mathbf{2 0 , 8 6}$ \\
\hline WU1 śr. & $\mathrm{x}$ & 0,0002 & 0,0000 \\
\hline WU2 śr. & 0,0002 & $\mathrm{x}$ & 0,0000 \\
\hline WU3 śr. & 0,0000 & 0,0000 & $x$ \\
\hline
\end{tabular}

Źródło: badania własne.

Test WI. Początkowy, przedwysiłkowy czas potrzebny na wykonanie próby w teście WI wyniósł średnio 5,58 s, by zaraz po treningu wzrosnąć do 5,76 s, przy czym różnica ta jest nieistotna. Po sześciu tygodniach ćwiczeń, podczas kolejnego badania średnie wyniki grupy wyniosły odpowiednio 5,56 i 5,36 s. Podczas ostatniego badania średnie wyniosły: 5,48 przed i 5,18 s po treningu.

Tabela 4. Wyniki testu wstań-idź. Próby przed- i powysiłkowe

\begin{tabular}{|l|c|c|c|c|c|c|}
\hline $\begin{array}{c}\text { Wyszczegól- } \\
\text { nienie }\end{array}$ & Wl1przed & WI1po & WI2przed & WI2po & WI3przed & WI3po \\
\hline Średnia & 5,58 & 5,76 & 5,56 & 5,36 & 5,48 & 5,18 \\
\hline $\begin{array}{l}\text { Odchylenie } \\
\text { standardowe }\end{array}$ & 0,74 & 0,87 & 0,85 & 0,76 & 0,76 & 0,73 \\
\hline $\begin{array}{l}\text { Istotność } \\
(p<0,05)\end{array}$ & \multicolumn{2}{|c|}{0,1335} & \multicolumn{2}{c|}{0,4855} & \multicolumn{2}{c|}{0,0052} \\
\hline
\end{tabular}

Źródło: badania własne.

Po określeniu wpływu treningu na uzyskiwane wartości, uśredniono wyniki prób przed- i powysiłkowych, które wyniosły odpowiednio: 5,67 dla pierwszego pomiaru, 5,46 dla drugiego oraz 5,33 s podczas pomiaru końcowego. Poniższa tabela ukazuje owe wyniki wraz z określeniem prawdopodobieństwa dla testów post hoc, za pomocą testu Bonferoniego. Istotność przy $p<0,05$.

Tabela 5. Uśrednione wyniki testu WI wraz z wynikami testu post hoc Bonferoniego

\begin{tabular}{|l|c|c|c|}
\hline \multirow{2}{*}{ Wyszczególnienie } & \multicolumn{3}{|c|}{ Badanie } \\
\cline { 2 - 4 } & $\{\mathbf{1}\} \mathbf{5 , 6 7}$ & $\{\mathbf{2}\} \mathbf{5 , 4 6}$ & $\{\mathbf{3} \mathbf{5 , 3 3}$ \\
\hline WI1 śr. & & 0,0716 & 0,0015 \\
\hline WI2 śr. & 0,0716 & & 0,5028 \\
\hline WI3 śr. & 0,0015 & 0,5028 & \\
\hline
\end{tabular}

Źródło: badania własne.

Określono wartość zmiany uśrednionego wyniku testu WI pomiędzy pierwszym a ostatnim badaniem dla każdego uczestnika. Nie zaobserwowano żadnych istotnych korelacji pomiędzy tym czynnikiem a wiekiem bądź wskaźnikiem BMI ćwiczących. 
Zarówno dla testu WU jak WI stworzono tabelę dwudzielczą, korzystając z następujących założeń:

- podział na trzy kategorie wiekowe $(\leq 65,66-70, \geq 71)$;

- podział na trzy kategorie zmian uzyskanych wyników: pogorszenie, niewielka poprawa $(\leq 30 \%)$, znaczna poprawa $(>30 \%)$.

Tabela 6. Zmiana wyników w teście WU ze względu na kategorię wiekową (test $X^{2}=0,046, V=0,44$ )

\begin{tabular}{|l|c|c|c|}
\hline \multirow{2}{*}{ Wyszczególnienie } & \multirow{2}{*}{ Pogorszenie } & \multicolumn{2}{|c|}{ Poprawa } \\
\cline { 2 - 4 } & & niewielka & znaczna \\
\hline$\leq 65(n=8)$ & 0 & 2 & 6 \\
\hline $60-70(n=10)$ & 0 & 7 & 3 \\
\hline$\geq 71(n=7)$ & 2 & 3 & 2 \\
\hline Ogółem & 2 & 12 & 11 \\
\hline
\end{tabular}

Źródło: badania własne.

Tabela 7. Zmiana wyników w teście WI ze względu na kategorię wiekową (test $\mathrm{X} 2 \mathrm{p}=0,154, \mathrm{~V}=0,36$ )

\begin{tabular}{|l|c|c|c|}
\hline \multirow{2}{*}{ Wyszczególnienie } & \multirow{2}{*}{ Pogorszenie } & \multicolumn{2}{|c|}{ Poprawa } \\
\cline { 3 - 4 } & & niewielka & znaczna \\
\hline$\leq 65(n=8)$ & 2 & 3 & 3 \\
\hline $66-70(n=10)$ & 1 & 5 & 4 \\
\hline$\geq 71(n=7)$ & 4 & 0 & 3 \\
\hline Ogółem & 7 & 8 & 10 \\
\hline
\end{tabular}

Źródło: badania własne.

\section{Podsumowanie}

Po 13-tygodniowym cyklu ćwiczeń uwidoczniła się wyraźna poprawa uzyskiwanych wyników w teście wstań-usiądź, gdzie 23 z 25 osób odnotowało wzrost średniej liczby powtórzeń, w tym 11 osób znaczny. Średnio poprawa pomiędzy pierwszym a ostatnim badaniem wyniosła $24 \%$. Wyniki pierwszego pomiaru ujawniły spadek siły po treningu o 11\%, co należy interpretować jako wpływ zmęczenia przy braku przygotowania organizmu na zaproponowaną formę ćwiczeń. Po 6 tygodniach ćwiczeń nie zaobserwowano istotnej zmiany wyników przed i po treningu, co z kolei sugeruje wzrost wytrzymałości dolnych partii mięśniowych. W ostatnim badaniu tendencja ta potwierdza się, ulegając pogłębieniu, tzn. wynik powysiłkowy okazał się o 7\% lepszy niż ten sprzed treningu, kiedy mięśnie były wypoczęte. Świadczy to o poprawie wytrzymałości mięśni na zaproponowaną aktywność ruchową.

Wyniki testu wstań-idź cechuje mniejsza zmienność, choć i tu uzyskano poprawę wyników: średnio, po 13 tygodniach ćwiczeń wyniosła ona 6\%. Podobnie jak przy wynikach testu wstań-usiądź, potwierdzenie znajduje tendencja do wzrostu 
wytrzymałości. Uczestnicy w pierwszym badaniu bezpośrednio po treningu mieli wynik gorszy o niecałe 4\% niż przed treningiem, po 6 tygodniach po treningu wynik próby powysiłkowej był już lepszy o niemal 4\%. W ostatnim badaniu różnica ta wyniosła $6 \%$ na korzyść próby powysiłkowej. Zaobserwowano, że wraz z wiekiem u uczestników badań spadała zdolność do poprawy wyników w obu testach.

Podczas kwalifikowania uczestników do programu badań powstały wątpliwości, czy jasnego obrazu uzyskanych wyników nie zaburzą różnice w masie ciała badanych, gdyż rozrzut w tym zakresie był znaczny: najlżejsza kobieta miała masę ciała równą 48,4 kg, najcięższa $94 \mathrm{~kg}$. Obawiano się bowiem, że osoby otyłe mogą nie być w stanie wykonać niektórych ćwiczeń lub będąje wykonywać nieprawidłowo, bez należytej intensywności, co z kolei zaburzyłoby otrzymane wyniki. W związku z tym postanowiono określić wskaźnik BMI dla każdego uczestnika celem znalezienia ewentualnych korelacji między masą ciała a zmianami w osiąganych wynikach podczas poszczególnych pomiarów. Przeprowadzona analiza nie ujawniła istotnych związków w przypadku obu testów. Dzięki temu można założyć, że rozrzut w masie ciała uczestników nie przełożył się bezpośrednio na uzyskiwane wyniki.

Wyniki przeprowadzonych badań obarczone są ograniczeniami. Do najważniejszych należy zaliczyć brak odniesienia do nieaktywnej ruchowo grupy kontrolnej celem wyizolowania istotnych czynników mających bezpośredni wpływ na uzyskane zmiany. Niewątpliwie pomocna w interpretacji wyników byłaby również ankieta wypełniona przez uczestników na początku i na końcu programu. Należałoby przeanalizować związki pomiędzy uzyskanymi wynikami w testach ruchowych z odpowiedziami badanych na pytania dotyczące między innymi aktywności ruchowej w przeszłości oraz obecnej, przebytych i obecnych chorób, charakteru pracy, trybu życia itp. Tylko dzięki takim zabiegom można określić realny wpływ zaproponowanego programu aktywności ruchowej na poprawę badanych zdolności motorycznych. Niemniej wydaje się, że uzyskane wyniki (szczególnie wyraźna poprawa średniej liczby powtórzeń w teście wstań-usiądź oraz poprawa wyników powysiłkowych względem przedwysiłkowych) pozwalają optymistycznie patrzeć na możliwość kształtowania oraz podnoszenia poziomu wybranych zdolności motorycznych u starszych osób, między innymi poprzez wykonywanie gimnastycznych ćwiczeń kształtujących.

\section{Wnioski}

Wyniki przeprowadzonych badań pozwalają na sformułowanie następujących wniosków:

1. Zrealizowany w ramach badań 13-tygodniowy program gimnastycznych ćwiczeń kształtujących poprawia:

- siłę mięśni zginających i prostujących kończyny dolne oraz tułów u kobiet po 60. roku życia,

- zwinność dynamiczną u kobiet po 60. roku życia,

- wytrzymałość mięśni zginających i prostujących kończyny dolne oraz tułów u kobiet po 60. roku życia. 
2. W grupie kobiet po 60. roku życia wraz z wiekiem obniża się podatność na poprawę siły mięśni zginających i prostujących kończyny dolne oraz tułów, uzyskiwaną dzięki 13-tygodniowemu programowi gimnastycznych ćwiczeń kształtujących.

3. Poprawa siły mięśni zginających i prostujących kończyny dolne oraz tułów kobiet po 60. roku życia, wskutek uczestnictwa w 13-tygodniowym programie gimnastycznych ćwiczeń kształtujących, jest niezależna od wskaźnika Body Mass Index.

\section{Literatura}

Drabik J., 1999, Aktywność fizyczna w kształtowaniu zdrowia człowieka - korzyści i zagrożenia, „Wychowanie Fizyczne i Sport", nr 4, s. 124-125.

Frontera W.R., Meredith C.N., O'Reilly K.P., Knuttgen H.G., Evans W.J. 1988, Strength conditioning in older men: skeletal muscle hypertrophy and improved function, „Journal of Applied Physiology”, vol. 64 (3), s. 1038-1044.

GUS, Rocznik demograficzny 2014, Zakład Wydawnictw Statystycznych, Warszawa.

Haskell W.L., Lee I.M., Pate R.R. i wsp. 2007, Physical activity and public health: updated recommendation for adults from the American College of Sports Medicine and the American Heart Association, „Circulation”, vol. 116, s. 1081-1093.

Maciatowicz J., 2003, Ruch fizyczny o charakterze wytrzymałościowym (biegi) zapobiega starzeniu się, leczy z patologicznych chorób społecznych, „Medycyna Sportowa”, nr 4, s. 156-164.

Młokosiewicz H., 1979, Gimnastyka, PWN, Warszawa.

Osiński W., 2013, Gerokinezjologia, Wydawnictwo PZWL, Warszawa, s. 173.

Rikli R.E., Jones C.J., 2002, Measuring functional fitness of older adults, „The Journal on Active Agin”, March April, s. 25-30.

Rubenstein L.Z., Josephson K.R., 2002, The epidemiology of falls and syncope. „Clinics in Geriatric Medicine", vol. 18(2), s. 141-58.

Skelton D.A., Greig C.A., Davies J.M., Young A., 1994, Strength, power and related functional ability of healthy people aged 65-89 years. „Age and Ageing”, vol. 23, s. 371-377.

Szczepaniak R., Brzuszkiewicz-Kuźmicka G., Szczepkowski M., Pop T., Śliwiński Z., 2014, Ocena aktywności ruchowej i sprawności fizycznej kobiet po 65 roku życia, ze zdiagnozowaną osteoporozą. Doniesienia wstępne, „Przegląd Medyczny Uniwersytetu Rzeszowskiego i Narodowego Instytutu Leków w Warszawie", nr 1, s. 62-73.

Thornby M.A., 1995, Balance and falls in the frail older person: A review of the literature. „Topics in Geriatrics Rehabilitation", vol. 11 (2), s. 35-43.

Zych A.A., 2001, Słownik gerontologii społecznej, Wydawnictwo Żak, Warszawa.

Żak M., 2000, Rehabilitacja w procesie leczenia osób starszych, „Gerontologia Polska”, nr 8, s. 12-18. 